David Allen

Midland Actors Theatre, UK

Agata Handley

University of Łódź

\title{
"The Most Photographed Barn in America": Simulacra of the Sublime in American Art and Photography
}

\section{ABSTRACT}

In White Noise (1985) by Don DeLillo, two characters visit a famous barn, described as the "most photographed barn in America" alongside hordes of picture-taking tourists. One of them complains the barn has become a simulacrum, so that "no one sees" the actual barn anymore. This implies that there was once a real barn, which has been lost in the "virtual" image. This is in line with Plato's concept of the simulacrum as a false or "corrupt" copy, which has lost all connection with the "original." Plotinus, however, offered a different definition: the simulacrum distorts reality in order to reveal the invisible, the Ideal.

There is a real building which has been called "the most photographed barn in America": the Thomas Moulton Barn in the Grand Teton National Park. The location-barn in the foreground, mountain range towering over it - forms a striking visual composition. But the site is not only famous because it is photogenic. Images of the barn in part evoke the heroic struggles of pioneers living on the frontier. They also draw on the tradition of the "American sublime." Ralph Waldo Emerson defined the sublime as "the influx of the Divine mind into our mind." He followed Plotinus in valuing art as a means of "revelation"-with the artist as a kind of prophet or "seer."

The photographers who collect at the Moulton Barn are themselves consciously working within this tradition, and turning themselves into do-ityourself "artist-seers." They are the creators, not the slaves of the simulacrum.

Keywords: simulacrum, sublime, DeLillo, Baudrillard, Plato. 
In the novel White Noise (1985) by Don DeLillo, two characters, Jack and his friend Murray, drive to see a famous barn, described as the "most photographed barn in America" (12). The episode has perhaps become "the 'Most Discussed Scene in Postmodern Fiction"” (Knight 39). Numerous road-signs show Jack and Murray the way to the site, where they find hordes of picture-taking tourists. They watch the photographers for a time; then Murray launches into a diatribe, interrupted only by silences and the clicking of the cameras. "No one sees the barn," he claims (DeLillo 12). Here are some of his observations:

"Once you've seen the signs about the barn, it becomes impossible to see the barn."

"We're not here to capture an image, we're here to maintain one. Every photograph reinforces the aura...."

"Being here is a kind of spiritual surrender. We see only what the others see.... A religious experience in a way, like all tourism.”

"They are taking pictures of taking pictures," he said.

"What was the barn like before it was photographed? ... What did it look like, how was it different from the other barns, how was it similar to other barns? We can't answer these questions because we've read the signs ..." (DeLillo 12-13)

Murray's words here echo Jean Baudrillard's analysis of the simulacrum-the notion that, in the age of the hyperreal, the image precedes the real. As Claire Colebrook observes, the barn in the novel is a simulacrum, in Baudrillard's terms,

precisely because it has no origin. You can only photograph the most photographed barn in America after it has been photographed; the process of imaging and simulation precedes and produces what the barn is. ... From a Baudrillardian point of view this is lamentable. We have lost all relation with actual barns - their place in farm life and rural culture-and fallen into a world where we value something only to the extent to which it has been copied. (97-98)

In the novel, Murray himself-a professor of popular cultureembraces the postmodern flux of signs; but the scene at the barn has most often been cited as "an articulation of the crisis of the real, of the mediation of our experience by the media” (Geyh 18). It is as if the picture-snapping 
visitors to the barn are poor benighted souls, in thrall to the "society of the spectacle"1_preferring the fake to the real.

Murray's references to "spiritual surrender," and tourism as a "religious experience," suggest that visitors to the barn become absorbed in the "aura" of fame and celebrity, and lose their individuality in a condition of "collective perception," which seems akin to a form of mass hypnosis. Joseph Tabbi and Michael Wutz suggest that when Murray says: "We can't get outside the aura. We're part of the aura. We're here, we're now" (DeLillo 13), the character expresses what Baudrillard called the "ecstasy of communication" (Tabbi and Wutz 17). It is as if the visitors to the barn are "prisoners" in a Platonic cave, fixated on, and even driven into a kind of rapture by, the endless stream of information and images cast on the cave wall. The term "aura" in this context appears to refer to the aura of the commodity, or what Baudrillard terms the "power and pomp of fascination" (4) of the simulacrum. In the silences when Murray isn't speaking, the only sounds are "the incessant clicking of shutter release buttons, the rustling crank of levers that advanced the film" (DeLillo 13). It seems the photographers are themselves part of a "machine" for producing images, to reinforce the "aura"; all they can do is keep clicking. Mark Schuster suggests that "they exist primarily to service the barn, to maintain, as Murray insists, its image. Just as the barn serves no other purpose than to be photographed, the tourists serve no other purpose than to photograph it" (16-17).

Baudrillard argues that in the age of mass communication, the image has become "weightless" (5) and circulates "in an uninterrupted circuit without reference or circumference" (6). It is detached from the real, and only refers to other images. In an internet blog, Leigh M. Johnson sees the barn in these terms, as "a sign with a referent so distant and distorted that meaning of the sign as sign became more meaningful than the meaning of its original referent." Johnson also notes that images of the barn appearing on websites such as "flickr" have "intensified the scene in DeLillo's novel to the nth degree. Now, we don't even have to physically visit the most photographed barn in America to (not) 'see it'" (emphasis original). In the novel, however, there is no attempt (by the character or the author) to explain why this particular barn should draw so many visitors, or why its image in particular should circulate so widely. The implication is that it is simply photographed because it is famous; and famous because it is so frequently photographed.

1 The phrase "society of the spectacle" is most closely associated with Guy Debord.

2 Johnson calls the website "Flixter" but he provides a link to flickr. 
When Murray asks: "What was the barn like before it was photographed ... ?", he implies that there is a "real" barn, an original, which we could see, if only we were not in thrall to the image. This is in line with Plato's concept of the simulacrum, at least "as he is usually read: the simulacrum is a copy of a copy, its untruth defined by its distance from the original" (Euben 144). In The Republic, Plato postulates a hierarchy of authenticity, using the example of a bed:

We have seen that there are three sorts of bed. The first exists in the ultimate nature of things, and if it was made by anyone it must, I suppose, have been made by God. The second is made by the carpenter, the third by the painter. (373)

In other words, there is an Idea of the bed, inhabiting the world of ideal Forms, and originating from the mind of God. The carpenter makes imperfect copies of the ideal Form; and the artist makes a copy of the carpenter's bed-i.e. a copy of a copy, and so corrupt. The artist imitates only the appearance of things, which are themselves only pale shadows of the Form. The simulacrum, in Plato's definition, is a distorted copy-for example, a statue which uses illusory effects such as false perspective: outwardly, it simulates the real thing, but this is only an effect of resemblance. Any link to the divine Form has been lost; but there is a danger that the spectator may nevertheless mistake the copy for the Idea or Form. ${ }^{3}$

Plato's famous parable of the prisoners in a cave, mesmerized by shadows cast on the cave wall, has frequently been conflated with Baudrillard's notion of hyperreality. Carl Plantinga, for example, observes:

Having never left the cave, and having no experience of that larger, extracavern universe, the cave-dwellers naïvely experience shadows on the wall as actuality, appearances as the real thing, these mere semblances as the "really real." Could this be our condition in today's world of media images? Have the misleading images on the cave wall been replaced by the relentless flickering lights of television and movie screens? $(307)^{4}$

3 Deleuze argues that the Platonian hierarchy of being leads to an endless and futile quest to distinguish "good from bad copies," imago from simulacrum (Logic 298).

4 Plantinga goes on to note that postmodern theorists such as Baudrillard "revise Plato radically. They accept his claims about images as deceptive appearances that reveal nothing and produce no knowledge. But they take an enormous and fateful step beyond Plato, by denying the existence of any actuality or reality that may be revealed" (307). 
In fact, the metaphor of the cave implies something different. For Plato, the majority of ordinary people only see the material surface of reality, and do not see through it to the divine Forms themselves. He describes how a prisoner might leave the cave, and finally see the sunimplying the acquisition of special knowledge and vision into the realm of Forms. As James L. Porter notes, the cave for Plato is "an allegory for the ascent of the soul from the world of visible things to the immaterial world of intelligible things," and is, in this sense, an encounter with the "immaterial sublime" (471). For Plato, only the philosopher can achieve this level of insight, or guide others to see it (90).

Ironically, the metaphor of the cave is itself an image, a form of "shadow on the wall." 5 Plotinus, the Neoplatonist philosopher, broke with the Platonic view of art as a corrupt copy, to argue that it may distort reality in order, precisely, to reveal the invisible, the "forming principles [logoi] from which nature derives" (5.8.I: 34-40). His example was a statue of Zeus, which was not based on any model drawn from life, but rather, created the idea of Zeus, or "what Zeus would look like if he wanted to make himself visible" (5.8.I: 3440). In other words, it is an image which reveals the invisible or divine. In this way, art is not twice removed from the original Idea (as in Plato), but rather, it "stands at the point where things turn around and go back, where things return to the starting point on the path to the One [i.e. the spirit in all things]" (Besançon 50). From Plotinus, then, we may infer a very different definition of the simulacrum from the Platonic model. In Plotinus, the "false" image is deliberately detached from the real. The simulacrum in this sense does not refer to the real, but to the ideal; it seeks to participate in the Platonic "Idea." It changes the viewer's way of seeing, redirecting their gaze from the material to the immaterial, and affording them an insight into a "transcendental beauty" which "has all the hallmarks of the sublime" (Porter 609).

To return to the example of the "most photographed barn": it may be argued that the multiple images of "pioneer" barns, in photographs, paintings and films etc., continually affirm and reinforce the (Platonic) Idea of "the barn." In other words: each image represents the ideal of all barns, rather than some actual/individual barn. In part, it celebrates the place of barns in American mythology, as an icon of "pioneer" life on the frontier.

There is an actual building which has been called "the most photographed barn in America."6 It is the Thomas Alma Moulton Barn,

5 Plato himself apologizes for speaking in images and explains that his own insight into the realm of Forms is not strong enough for him to speak more directly and literally. See Fine (95).

${ }_{6}$ The barn was evidently proclaimed the "most photographed barn in America" in 1994 by Country Extra magazine (see Storrow)—perhaps in reference to DeLillo's novel. 
which stands on Mormon Row (now within the Grand Teton National Park). The location partly explains why it is so popular as an image: the combination of the barn in the foreground, and the Grand Teton mountain range behind, forms a striking visual composition. Keith Wilson, in Vierefinder: 100 Top Locations for Great Travel Photography, writes that the barn, when photographed in snow, "gives you an idea of the isolation the early settlers must have felt during their first winters" (43). The solitary barn, dwarfed by the mountains towering over it, evokes the heroic struggle of those early homesteaders, to stake a foothold on this wild, majestic, but daunting frontier. In this way, its "real" history (i.e. what it was like before it was photographed) has been subsumed in a wider social narrative: the myth of the American frontier. In this sense, it is now more "virtual" than "actual"; more "ideal" than "real." It is true, then, that we cannot simply see the Moulton barn as a particular barn, in a particular setting; we cannot go back to what the barn looked like before it was photographed. Rather, it stands for all "pioneer" barns, and represents the "essence" of frontier life. On this level, the appeal of the building might simply be said to be based in nostalgia. This accords with Fredric Jameson's argument that, in the postmodern age, history has been replaced by a new aesthetic "nostalgia mode" (28), where the past is consumed through a glossy pastiche of styles. (There may be an echo here of Baudrillard, who wrote: "When the real is no longer what it used to be, nostalgia assumes its full meaning" [6].) The "nostalgia mode" satisfies a craving for history, even as it turns the past into "a vast collection of images, a multitudinous photographic simulacrum” (Jameson 26). An image such as the barn, then, appears to form part of a shared imaginary, a myth of the past, which obliterates real history, existing "beyond real historical time" (Jameson 29).

It is clear, however, that Jameson is wedded to the (Baudrillardian) idea that, in the "society of the spectacle," the "real" has been lost, in the endless play of surfaces. He condemns the simulacrum as a corrupt (false) copy of the "real." He even uses the image of Plato's cave: postmodern cultural production, he argues, "can no longer look directly out of its eyes at the real world but must, as in Plato's cave, trace its mental images of the world on its confining walls" (33). Jameson (like Baudrillard) seems to cast himself in the Platonic role of the philosopher who has escaped from the "cave" of illusions and can guide the rest of us to the "light." Arguably, however, the simulacrum was never about the representation of "real" history, but always about reaching beyond the visible/real, to the unreal, the ideal.

The photographer J. Riley Stewart has described the process he went through in photographing the Moulton Barn. He saw it as telling a story 
of human struggle on the high plains of the Grand Teton mountain range. The main subject was the old abandoned barn, dominated by the eternal, massive, menacing mountain range. To me, it was a story of humanity's neverending [sic] fight with nature: in this case a battle lost by those who abandoned their homestead simply to survive. ("Revelations")

This has little to do, of course, with the actual barn, or the actual history of the people who lived there. In fact, there is no interest in the barn as a "real" place. Instead, there is a conscious construction of the image as simulacrum. Ostensibly, Stewart was creating an image of pioneer life, in the "nostalgia mode." However, it is evident that he was also pointing to other meanings or themes: the fragility of life, and human transience in the face of the "eternal" forces of nature etc. In this sense, he is not simply telling a story but creating the image as a kind of capsule, to contain or embody an Idea.

Stewart is not in thrall to the image; rather, he is using the medium, and (like Plotinus's artist-figure) distorting the "real," to tell his chosen "story." In photographing the barn, he approached the task with what we might term a "camera consciousness" - an awareness of the image as image. In his blog, he describes how he constructed the image, focusing on the barn with a zoom lens, to isolate it from the surroundings; and using a vertical perspective, with the barn near the bottom of the frame, and the mountains looming over it, to create "an illusion of pressure and force of nature upon it" ("Revelations"). He also modified the lighting in the shot, to highlight the barn as the "leading character" of the "story," and darkening the mountains "to make them appear menacing and stark" ("Revelations"). Stewart also shows an awareness of artistic influences on his work. In a separate article called "A Study in Luminosity" (published online alongside the blog on the Moulton Barn), he discusses the dramatic use of light in nineteenth century "luminist" art, "where it appears as if God created a huge spotlight to illuminate the subjects." He notes that it is the interplay between light and shadow which creates the emotional impact of luminist art: luminosity "gives us hope in the knowing," whereas dark shadows make us "wary and uncertain" ("Luminosity"). It is evident that, in his barn photo, Stewart was not simply creating a pastiche of the luminists' style; rather, his own interest in the style was as a language or "code" of the "immaterial sublime" (Porter 471). If there is nostalgia here, it is less for an aesthetic style or genre, than for the idea of an art form which is dedicated to revealing the invisible, the work of God.

The "most famous barn" phenomenon has to be seen, in fact, within the wider tradition of the "American sublime," which is associated in particular

7 The phrase "camera consciousness" is taken from Deleuze (Cinema 74). 
with artists of the luminist and Hudson River schools, such as Thomas Cole, Thomas Moran, and Albert Bierstadt. In Plotinian terms, these artists created simulacra of nature, distorting the "real" to lead the viewer's gaze "from the outer world to the world within" (Porter 609). Edmund Burke claimed that the sublime must evoke a sensation of "astonishment" in the viewer (95); Moses Mendelssohn compared it to "a lightning bolt, which blinds us in one moment and disappears the next" (qtd. in Franzel 100). This suggests a sudden, spontaneous, one-off event. The sublime in art, however, may be seen as the attempt, not simply to repeat or simulate this experience, but to create it.

In accounts of nineteenth century expeditions in the American wilderness, authors often used the language of the sublime to evoke some of the extraordinary sights they encountered. Here, for example, is how Nathaniel Langford, a member of the 1870 Washburn expedition, described seeing the Yellowstone Grand Canyon:

The brain reels as we gaze into this profound and solemn solitude.... Down, down, down, we see the river attenuated to a thread.... The solemn grandeur of the scene surpasses description. It must be seen to be felt.... You feel the absence of sound, the oppression of absolute silence. (qtd. in Meyer 61)

This account evokes a momentary experience in which the viewer is "stopped cold" by an overwhelming sight. However, we may see that Langford's account of the canyon echoes Burke, in the stress on "greatness of dimensions" (Burke 97), "Solitude, and Silence" (Burke 125), and a sense of "infinity" (Burke 129). Langford was seeing the canyon for the first time, and yet, far from this being a sudden and "one-off" event, he was effectively prepared for the experience. He went looking for the sublime in nature, and that is what he found. In this way, the "image" preceded the "real."

In her book The Spirit of Yellowstone (1996), Judith L. Meyer demonstrates how the reports published by the first "discoverers" of Yellowstone such as Langford influenced later accounts, in guidebooks etc. Describing the canyon, for instance, writers often talked about the "profound solitude and absolute silence" (Riley qtd. in Meyer 62) or "the sheer depth, the gloom" (Hoyt qtd. in Meyer 62). Tourists frequently spoke of their experience of the site in similar terms; they "told of the canyon's dizzying depth and a feeling of speechlessness, timelessness, and insignificance in the face of God or nature" (Meyer 63). The language of the sublime, then, had become conventional, suggesting that responses to nature were conditioned rather than spontaneous; or rather, perhaps, there was a desire by visitors to step, so to speak, inside the simulacrum: 
to stand where others have stood, and experience the idea of the sublime; in this sense, to take part in a "collective perception" (DeLillo 12). These accounts also affirmed the Yellowstone canyon itself as a special site, a kind of "power centre," ${ }^{8}$ where the sublime may be revealed.

A year after the Washburn expedition, the artist Thomas Moran joined the Hayden expedition to Yellowstone. His 1872 painting, The Grand Canyon of the Yellowstone, "marked the beginning of a career dedicated to painting radiant scenes of the sublime western landscape" (Miller 107). In this work, Moran sacralizes nature. At its centre is a waterfall: there is a stream of white, with an intensely glowing ball of light at its base, like a divine light shining through creation. A pillar of spray rises from the base, like smoke from a sacrificial altar. In this way, the scene is like a temple to nature. It appears that the artist is seeking to replicate the "one-off" experience of the sublime-an epiphany, or, to use Mircea Eliade's term, a "hierophany" (11); or rather, perhaps, we may say he is seeking to construct the experience for the viewer. In the foreground, there is a platform of rock, where two human figures stand, in a direct line below the waterfall; they are worshippers at this "temple." One of them is evidently intended to represent Hayden himself. He is an embodiment of the explorer: he faces the waterfall, his hand outstretched, as if in a gesture of admiration and awe. The figure is our surrogate in the painting, as viewers. The size of the canvas for the painting ( 7 foot by 12 foot) seems to draw us in (like a modern cinematic IMAX experience). Its very size emulates the grandeur or "greatness of dimensions" of the sublime.

Moran manipulated reality in his painting, adapting the layout of the valley to suit his purposes (Kinsey 54-55). This fact alone belies any suggestion that the work was based on a direct experience of the sublime in the landscape. Rather, the sublime was constructed in the image. It is a simulacrum, in the sense that it distorts the real to unveil the invisible. The painting also served as a record of a moment of discovery and conquest. Hayden's outstretched arm could suggest he is claiming possession of the land for the nation. This does not, however, contradict the idea of an encounter with the sublime. (Ralph Waldo Emerson, we may recall, associated the wilderness of American West with transcendence; he described it as "the yet untouched continent of hope glittering with all its mountains" [Collected 1 136].)

The painting rapidly spread as a commodity, appearing in magazines and guidebooks; and it played a particular role in promoting Yellowstone Park as a tourist destination. In its endless circulation, however, the image did not (pace Baudrillard) become detached from the "real," as it was always-already unreal. Its appeal was not simply the "aura" of celebrity;

8 For the concept of the "power centre," see Lake. 
rather, it functioned as a kind of quasi-religious icon, as if the sublime, the supra-natural, was immanent in the work itself. Every copy of the image in circulation was a repetition, and exploitation, of this occult "power."

Joni Kinsey notes that guidebooks of the 1880 s

presented the canyon as an embodiment of the spirit of the entire national park, and in describing the scene writers invariably referred not just to the natural setting, which many of them had never seen, but implicitly to Moran's more accessible image. (66)

Ordinary visitors, it seems, followed suit. (One of them, for example, wrote: "From its foot, like incense before an altar of silver, rises the mist eternally" [Atwood qtd. in Rubinstein, Whittlesey and Stevens 43]). Visitors perhaps believed — or wanted to believe-that they were, themselves, having a "unique" and spontaneous experience of nature; but we can see how far it was actually pre-formed or mediated. It could be argued that they could no longer "see" the canyon-or could only see it as if it was a painting by Moran. Arguably, however, this was the point. Visitors wanted to see what Moran saw; they wanted, in other words, to step inside the simulacrum. However, there must have always been an awareness, for visitors, of a certain gap, a mismatch between the image, and the actual place. For one thing, as we have seen, the painting misrepresented the geography of the valley. Moreover, it employs a combination of elements—such as the sacred light of the waterfall—which do not represent the "real" landscape, but rather the ideal of the sublime. Paradoxically, it is as if the painting is the "original," because it is the ideal (Platonic) Form; and the reality is the poor copy.

Today, the place where Moran is thought to have painted the canyon is known as Artist Point. If this is hallowed ground, however, it is because Moran made it sacred; and because it is the spot where he created his masterwork. One modern guide book advises visitors that the spot is "beset by the masses of digital shutterbugs," but "you'll still find the occasional painter and wideformat photographer. Remember, to them this is hallowed ground. Please give them room to work and respect their concentration" (Waypoint Tours 42). The implication is that contemporary artists and photographers are seeking to follow Moran's lead, and capture the invisible through their art.

\section{EMERSON's “TRANSPARENT EYEBALl”}

As we have seen, descriptions of the Yellowstone canyon in early guidebooks etc., often followed Langford in using the language of the sublime. Meyer notes, however, that in time, there was a shift in language: 
Langford's "painful silence" changed to "a reverent hush" (Meyer 63). In 1878, for example, Edwin Stanley wrote, on seeing the Yellowstone canyon: " $[W]$ e were awed into silence and reverence, feeling that we were in the very antechamber of the great God of Nature, and that he was talking to us and teaching us lessons of his greatness, his grandeur, and his glory" (77-78). Barbara Novak notes that the concept of the American sublime in the nineteenth century was increasingly "Christianized" (33). The beginning of this shift is observable as early as 1835 in the "Essay on American Scenery" by the painter, Thomas Cole, who urged his readers to

\section{Learn}

The laws by which the Eternal doth sublime

And sanctify bis works, that we may see

The bidden glory veiled from vulgar eyes. (Cole 36; italics original)

An even more significant and influential shift may be found in Emerson's writings. He defined the sublime as "the influx of the Divine mind into our mind" which comes from "the heart of nature": "We distinguish the announcements of the soul, its manifestations of its own nature, by the term Revelation. These are always attended by the emotion of the sublime" (Collected 2 166-67; italics original). In his essay "Nature" (1836), Emerson made what has been seen as founding statement of American transcendentalism. Evoking a moment of epiphany, he wrote:

Standing on the bare ground,-my head bathed by the blithe air, and uplifted into infinite spaces,-all mean egotism vanishes. I become a transparent eye-ball. I am nothing. I see all. The currents of the Universal Being circulate through me; I am part or particle of God. (Collected 1 10)

In other words: Emerson's "pupil” sees through the material surface of reality, to "apprehend that flow of animating energy otherwise known as Spirit" (Gatta 89). For Emerson, there is a force or spirit emanating throughout the universe, an ontological univocity of Being which he termed the "OverSoul" (and Plotinus called the "One"). ${ }^{10}$ Emerson regarded the natural

9 See Harrison (84-85).

10 Alain Badiou has argued that the concept of an ontological univocity of being implies that "beings are all identically simulacra and all affirm . . . the living Power of the One" (25). He shows how the Deleuzian concept of the "simulacrum" may be related to Deleuze's own affirmation (in The Logic of Sense) of the "univocity of Being" (Logic 179); see Badiou (23-28). Emerson's essay, "The Over-Soul" is published in Emerson Collected 2 (157-76). 
world as a kind of "coded poem" which the individual seeks to penetrate, in order to understand the language of God: "Every natural fact is a symbol of some spiritual fact" (Collected 1 18). Most people, he believed, only see the phenomenal surface of matter; what they needed was "a general education of the eye" (Later Lectures 62). He elevated the poet as "seer," just as Plato elevated the philosopher. The poet, he wrote, "turns the world to glass" (Collected 3 12) -i.e. he/she sees the "invisible," and makes it "translucid to others" (Collected 3 15). In the essay "The Poet" (1841-43), he states that, when we read the poet's works correctly, "[w]e are like persons who come out of a cave or cellar into the open air" (Collected 3 17). In this way, Emerson followed Plotinus in seeing art, not as the Platonic "false copy," but as the means of revealing the Ideal. He recognized that the writer has to exercise judgement, to convert "nature into the rhetoric of thought"' (Collected 2 199); there is a combination of "spontaneous reception" of impressions from nature, and the "willful reproduction" of these impressions (Meehan 77). Arguably, however, in the "transparent eyeball" passage, Emerson himself went beyond "willful reproduction." His original notebook version of the passage was very different to the final version that appeared in "Nature": "Standing on the bare ground with my head bathed in the blithe air, \& uplifted into infinite space, I become happy in my universal relations. ... I am the heir of uncontained beauty \& power" (Journals 18). David Greenham suggests that, in the revised version, Emerson was reconstructing the experience at "a higher literary level in order to get beneath the experience to its very grounds" (85). But in fact, he uses language, not to reveal, but to sacralize the experience. He reconstructs it aesthetically; and in the process, he changes it. He goes from being happy in his "universal relations" to "all mean egotism vanishes." In other words, be eliminates the ego in the account. He turns what was originally recalled as a moment of simple happiness, into an epiphany. Crucially, the passage encapsulates the Neoplatonic idea of the "One" (or "Over-Soul")—-the moment of insight into the energy or Spirit flowing through matter. In other words, the experience was made to embody a pre-existing idea. In this prime statement of American transcendentalism, then, language itself operates as the medium, the "glass" (or "transparent eyeball"). Emerson creates the revelation of the "invisible" through his writing. Arguably, he is working on himself as a poet-seer and educating his own "eye."

\section{Ansel Adams and the Process of "Visualization"}

In the nineteenth and twentieth centuries, photographers such as Herbert Gleason and Ansel Adams followed in the tradition of the American sublime. Adams himself described the wilderness as 
"a mystique: a valid, intangible, non-materialistic experience" (qtd. in Turnage). He wrote: "the clear realities of Nature seen with the inner eye of the spirit reveal the ultimate echo of God" (Adams, Letters 248). While he used elements of the nineteenth century "code" of the sublime (such as the "God light"-i.e. shafts of light coming from the sky), it is clear that his images were not simply exercises in style but were based in the notion of divine "revelation" (Emerson, Collected 2 167); and he saw himself as an "artist-seer" in the Emersonian tradition. He used his camera to "see" with the "inner eye of the spirit" - as if it was the "transparent eyeball"- to guide others to witness the "clear realities of Nature" (Adams, Letters 248).

At the same time, Adams famously stated that "you don't take a photograph, you make it” (qtd. in Colley 15). He argued the need for what he termed "visualization," meaning a conscious process of seeing the final image in the mind's eye before actually taking the photograph. The implication of visualization is that the artist must use "willful reproduction" (Meehan 77) to reveal the "echo of God" (Adams, Letters 248); in other words, he/she is constructing the image as simulacrum. At the same time, there is an emphasis on the subjectivity of the artist. Adams stated: "Photography is a way of telling what you feel about what you see. And what you intuitively choose to see is equal in importance to the presentation of how you feel-which is also intuitive" (qtd. in Hammond 79). He observed, for example, that his 1941 photo Moonrise, Hernandez, New Mexico was "not at all realistic." He made the sky preternaturally dark because that "is how it felt" (qtd. in Sheff and Sheff, italics original). It might be argued, in Emersonian terms, that the artist is not simply expressing his feelings in the image but communing with nature and resonating in himself the "flow of animating energy otherwise known as Spirit" (Gatta 89). Nevertheless, it is clear that Adams is not so much revealing the unreal or invisible, as creating it in the image.

Clearing Winter Storm (c.1937) is a photograph of the Yosemite Valley, taken from New Inspiration Point. When it was published in the book This is the American Earth (1968), the accompanying text by Nancy Newhall read: "You shall face immortal challenges;. . . . You shall live lifted up in light; you shall move among clouds" (Adams and Newhall 106). Adams himself recalled how he came to photograph Clearing. He was looking for an opportunity to shoot Yosemite in a snowstorm as a "one-of-a-kind situation." He had "visualized" the image, but it took considerable time and preparation to achieve it. He found his opportunity when a break occurred in a snowstorm, and "the valley was revealed under a mixture of snow and clouds with a silver light gilding Bridal Veil 
Fall" (Adams and Alinder 203). But this was not the end of the matter: in processing the image, he used dodging and burning (lightening and darkening) to increase the contrasts (Examples 105). Clearly, Adams was waiting for a moment when the "God light" would break through, creating a contrast between reverence and awe, and terror. The swirling clouds overhead create a sense of invisible forces (or "Spirit") at work in the universe. The trees on the valley floor suggest a congregation of worshippers in this natural (or divine) "cathedral."

Thus, Clearing appears to represent a moment of epiphany; but this is carefully constructed in the image. It has also become celebrated as a legendary moment in the history of photography, when the heavens literally opened, and gave Adams the image he wanted. Shaoni Bhattacharya notes that the "romance and wildness" of the image "belies the fact Adams shot it from a parking lot, and that in fact the view should show human trails and paths etched into the mountainsides, but the camera angle chosen obscures them" (Bhattacharya). But the inclusion of signs of human presence would have introduced the "profane" into this image of the "sacred."

Clearing has been reproduced in countless posters, calendars and books etc. In this sense, it has acquired the aura of a "celebrity" commodity. But it has also become a quasi-religious icon, a metonym for this moment of vision by the artist-as-seer. As in Moran's painting, the multiplying copies seek to replicate and exploit the "sacred power" which is immanent in the image. At the same time, the artist himself has acquired celebrity status; so what speaks through the image, in part, is Adams himself, and his skill in creating memorable images of the sublime.

Adams is a continuing influence on landscape photographers. There are blogs online with titles such as "Learn Ansel Adams' Biggest Secret for Stunning Photography-Visualization" (Silber) or "Nature Photography: Think Like Ansel Adams Today" ("Nature Photography"). Peter Essick notes that some photographers even try "to go back to the exact shot and re-photograph standing in the tripod holes' of where Adams stood" (qtd. in Leary). John Kasaian has observed groups of photographers at Tunnel View, where Adams shot Clearing, "standing around waiting for snow to stop falling." Arguably, the aim is not simply to take photos like Adams, but to re-experience, if not some religious epiphany, then the moment of capturing the perfect image. Even where photographers want to create an original image of their own, they may still be trying to think like the "master," to follow him like a "prophet" or artist-seer. In this way, there is an urge to copy, to reproduce; but this is not the same relationship to the image as the one evoked by DeLillo in White Noise. 


\section{The Photographer as Pilgrim}

America's national parks are littered with places which have effectively been turned into "power centres" through the images associated with them-Yellowstone Grand Canyon, New Inspiration Point, Half-Dome etc. We do not, perhaps, see these sites literally as places where the sacred meets the profane; but they have become famous as sites where artist-seers such as Moran and Adams achieved artistic, if not religious, "epiphanies." The modern "pilgrim" follows trails through the parks with their own camera, as if in footsteps of these artist-seers. There are photography guidebooks and websites for visitors, which are akin to pilgrimage guides. Following them gives photographers opportunities to exercise their skills, and to become do-it-yourself artist-seers. This is about far more than "taking pictures of taking pictures" (DeLillo 13); it is a form of individual, physical re-enactment of the process whereby key sites were constructed as simulacra of the sublime. For the Grand Tetons, for example, essential locations on the photographic trail include Snake River Overview-where Adams took his famous shot of The Tetons and the Snake River (1942); Oxbow Bend; and the Thomas Moulton Barn.

We may see how the barn is a gift to photographers for crafting images of the sublime. Arguably, the meaning of the barn-for everyone apart from the Moulton family themselves-has long been as image. The building itself evokes something of the aura of the "sacred site." The shape of the roof recalls a church; and it matches the angle of the mountain peak, as if the two are mystically aligned.

Photographers exchange tips online on how to capture the best shots of the barn; for example: "If you are going to do the Mormon barns, get there for sunrise ... you'll have lots of company. That is when the lighting is best for this spot" ("em-T-sails"). In response to a photograph on the internet (by Mike Hall), showing the barn at dawn, one viewer commented: "Magical lighting! As if this beautiful landscape is bathed in sacred light!" (Hall). These comments suggest that a visit to the site is not a form of "spiritual surrender" (DeLillo 12). Photographers are not there to surrender to the "aura" of the image, but to construct the simulacrum for themselves. If they see themselves as channeling anything, it is the "spirit" of their artistic forebears-even appropriating something of their celebrity "aura"; as if they remain not simply models to follow, but "spirit guides." For example, one photographer (Jeff Clow) described his shot of the barn as an attempt "to channel my inner Ansel Adams." A comment by a fellow photographer on Clow's "flickr" page, where the image is published, reads: "Yep, for sure Ansel is inside you somewhere" (Clow). 
In Clow's image, there is a strong emphasis on shape. The barn mirrors the mountain behind it; and the bank of clouds in the sky seems to mirror both the mountains, and the trees in the foreground. It is as if the human, the natural, and the supra-natural, are all merging, in an image of what Emerson called the "eternal One" (Collected 2 160). Nevertheless, it may be argued that Clow's work is simply a pastiche. Other comments posted by visitors to his "flickr" page suggest that the primary interest in fact lies in questions of composition and technique, rather than in the image as an "echo of God" (Adams, Letters 248); for example: "The textures and depths are fantastic. Has a vintage feel to this beautiful view," and "[b] eautiful shot... love the clouds and processing. Is this a HDR?" (Clow).

Thomas Weiskel has suggested that the sublime might be a "moribund aesthetic" in an age when "we have lost the obsession, so fundamental to the Romantic sublime, with natural infinitude" (6). Ironically, then, it might be argued that the problem is not that the image has become detached from the "real" (i.e. the "actual" barn); but rather, that it has become detached, to some degree at least, from the Ideal. Arguably, however, the idea has not died out, but rather persists as a presence in much landscape photography, however obscured it may seem by all the technical talk about filters, exposure, balance etc. In an editorial in an issue of Aperture magazine, it was argued:

While belief in a God as an undeniable reality or as an abstract concept is often in debate, many people believe in or sense an otherness ... be an inherent factor in humankind's experience. These "moments of grace," these so-called epiphanies ... are more or less intuitive perceptions or insights into the reality or essential meaning of something. . . Photographers have described a "moment of grace," when they are unexpectedly able to create an image of lasting meaning and revelation. (Bridges 2)

Aperture was founded in 1952 by a group of photographers including Ansel Adams; so it is perhaps not surprising to find it continuing to affirm the idea of spiritual "revelation." Arguably, however, the idea is also evident in the work of photographers such as Eliot Porter and Peter Essick. (One contemporary photographer, John Parkinson, describes his book of landscape images, Visual Verse [2006], as a collection of "God's Art" [vii].)

In a blog called "8 Lessons Ansel Adams Can Teach You About Photography," Eric Kim urges his readers: "Photograph with your emotion, and your entire soul." Similarly, in the book Digital Landscape Photography: In the Footsteps of Ansel Adams and the Great Masters, Michael Frye recommends paying attention to light and weather, and using "every possible visual tool- 
line, shape, pattern, tone, color, movement, exposure, and depth of field-to emphasize the feeling you're trying to convey" (54). We may see, then, that the romantic concept of the "artist-seer" endures. Moreover, it is clear that technique is being used by photographers to shape the image-i.e. making, not taking photos (as Adams advised). There is a pleasure in the ability to transform the real and produce images of landscapes as "power centres." Arguably, photographers accrue a sense of their own authority as "artistseers," through their ability to construct the "power" in the image. They are the creators, not the slaves of the simulacrum.

\section{Works Cited}

Adams, Ansel. Ansel Adams: Letters and Images, 1916-1984. Ed. Mary Street Alinder and Andrea Gray Stillman. Boston: Little, 1988. Print.

---. Examples: The Making of 40 Photographs. Boston: Little, 1989. Print.

---, and Mary Street Alinder. Ansel Adams: An Autobiography. Boston: Little, 1996. Print.

---, and Nancy Newhall. This is the American Earth. San Francisco: Sierra Club, 1968. Print.

Badiou, Alain. Delewze: The Clamor of Being. Trans. Louise Burchill. Minneapolis: U of Minnesota P, 2000. Print.

Bhattacharya, Shaoni. "Ansel Adams: Capturing Wilderness on Camera." Nerescientist.com. New Scientist 14 Nov. 2012. Web. 8 Apr. 2018.

Baudrillard, Jean. Simulacra and Simulation. Trans. Sheila Glaser. Ann Arbor: U of Michigan P, 1994. Print.

Besançon, Alain. The Forbidden Image: An Intellectual History of Iconoclasm. Trans. Jane Marie Todd. Chicago: U of Chicago P, 2000. Print.

Bridges, Thomas. "Moments of Grace: Spirit in the American Landscape." Aperture 150 (Winter 1998): 2. Print.

Burke, Edmund. A Philosophical Enquiry into the Origin of Our Ideas of the Sublime and Beautiful. London: Dodsley, 1767. Print.

Clow, Jeff R. "Ansel Tribute at the Barn.” Flickr.com. Web. 8 Apr. 2018.

Cole, Thomas. "Essay on American Scenery." The Native Landscape Reader. Ed. Robert E. Grese. Amherst, MA: U of Massachusetts P in association with the Library of American Landscape History, 2011. 27-36. Print.

Colebrook, Claire. Gilles Deleuze. London: Routledge, 2002. Print.

Colley, Paul. Winning Images with Any Underwater Camera: The Essential Guide to Creating Engaging Photos. Oxford: Dived Up, 2014. Print.

Debord, Guy. The Society of the Spectacle. Trans. Ken Knabb. Berkeley, CA: Bureau of Public Secrets, 2014. Print. 
Deleuze, Gilles. Cinema 1: The Movement-Image. Trans. Hugh Tomlinson and Barbara Habberjam. Minneapolis: U of Minnesota P, 1986. Print.

---. The Logic of Sense. Trans. Mark Lester and Charles Stivale. London: Continuum, 2004. Print.

DeLillo, Don. White Noise. London: Penguin, 1985. Print.

Eliade, Mircea. The Sacred and the Profane: The Nature of Religion. Trans. Willard R. Trask. Orlando: Harcourt, 1987. Print.

Emerson, Ralph Waldo. Journals and Miscellaneous Notebooks of Ralph Waldo Emerson. Vol. 5. Ed. Merton M. Sealts. Cambridge, MA: Belknap P of Harvard UP, 1965. Print.

---. The Collected Works of Ralph Waldo Emerson. Vol. 1: "Nature, Addresses, and Lectures." Ed. Robert E. Spiller and Alfred R. Ferguson. Cambridge, MA: Belknap P of Harvard UP, 1971. Print.

---. The Collected Works of Ralph Waldo Emerson. Vol. 2: "Essays: First Series." Ed. Joseph Slater, Alfred R. Ferguson and Jean Ferguson Carr. Cambridge, MA: Belknap P of Harvard UP, 1979. Print.

---. The Collected Works of Ralph Waldo Emerson. Vol. 3: "Essays: Second Series.” Ed. Joseph Slater, Alfred R. Ferguson and Jean Ferguson Carr. Cambridge, MA: Belknap P of Harvard UP, 1983. Print.

---. The Later Lectures of Ralph Waldo Emerson: 1843-1871. Athens, GA: U of Georgia P, 2001. Print.

“em-T-sails.” "Re: Best Photography Spots for 1 or 2 Day Visit." Tripadvisor. co.uk. 28 Mar. 2010. Web. 8 Apr. 2018.

Euben, J. Peter. Platonic Noise. Princeton, NJ: Princeton UP, 2003. Print. Fine, Gail. "Knowledge and Belief in Republic V-VII." Epistemology. Ed. Stephen Everson. Cambridge: Cambridge UP, 1990. 85-115. Print.

Franzel, Sean. "Time and Narrative in the Mountain Sublime Around 1800." Heights of Reflection: Mountains in the German Imagination from the Middle Ages to the Twenty-First Century. Ed. Sean Moore Ireton and Caroline Schaumann. Rochester, NY: Camden, 2012. 98-115. Print.

Frye, Michael. Digital Landscape Photography: In the Footsteps of Ansel Adams and the Great Masters. London: Ilex, 2009. Print.

Gatta, John. Making Nature Sacred: Literature, Religion, and Environment in America from the Puritans to the Present. Oxford: Oxford UP, 2004. Print.

Geyh, Paula E. "Assembling Postmodernism: Experience, Meaning, and the Space In-Between.” College Literature 230.2 (2003): 1-29. Print.

Greenham, David. Emerson's Transatlantic Romanticism. Houndmills: Palgrave Macmillan, 2012. Print.

Hall, Mike. "First Light on the T.A. Moulton Barn, Jackson Hole." Mhallphoto.animus3.com. 1 Nov. 2011. Web. 8 Apr. 2018.

Hammond, Anne. Ansel Adams: Divine Performance. New Haven: Yale UP, 2002. Print. 
Harrison, John S. Teachers of Emerson. New York: Haskell, 1966. Print. Jameson, Fredric. Postmodernism: Or, the Cultural Logic of Late Capitalism. Durham: Duke UP, 1991. Print.

Johnson, Leigh M. "The Most Photographed Barn in America." Readmorewritemorethinkmorebemore.com. 10 Dec. 2007. Web. 8 Apr. 2018.

Kasaian, John. "Re: Ansel Adams' Clearing Winter Storm." Largeformatphotography.info. 14 Sept. 2016. Web. 8 Apr. 2018.

Kim, Eric. "8 Lessons Ansel Adams Can Teach You About Photography." Erickimphotography.com. Web. 8 Apr. 2018.

Kinsey, Joni. Thomas Moran and the Surveying of the American West. Washington: Smithsonian Institute, 1992. Print.

Knight, Peter. "DeLillo, Postmodernism, Postmodernity." The Cambridge Companion to Don DeLillo. Ed. John N. Duvall. Cambridge: Cambridge UP, 2008. 27-41. Print.

Lake, Medicine Grizzlybear. "Power Centers." The Power of Place: Sacred Ground in Natural and Human Environments. Ed. James A. Swan. Wheaton, IL: Quest, 1991. 48-59. Print.

Leary, Catie. "Photographer Traces Ansel Adams' Footsteps in Breathtaking New Book.” Mnn.com. 24 Apr. 2014. Web. 8 Apr. 2018.

Meehan, Sean Ross. Mediating American Autobiography: Photography in Emerson, Thoreau, Douglass, and Whitman. Columbia, MO: U of Missouri P, 2008. Print.

Meyer, Judith L. The Spirit of Yellowstone: The Cultural Evolution of a National Park. Lanham, MD: Rowman, 1996. Print.

Miller, Angela. "The Fate of Wilderness in American Landscape Art: The Dilemmas of 'Nature's Nation.'” American Wilderness: A New History. Ed. Michael Lewis. Oxford: Oxford UP, 2007. 91-112. Print.

"Nature Photography: Think Like Ansel Adams Today." Outdoorphotographer.com. 3 Feb. 2009. Web. 8 Apr. 2018.

Novak, Barbara. American Landscape and Painting, 1825-1875. Oxford: Oxford UP, 2007. Print.

Parkinson, John. Visual Verse: Art in Nature with Symbiotic Verse. Austin, TX: Synergy, 2006. Print.

Plantinga, Carl. "Moving Pictures and the Rhetoric of Nonfiction: Two Approaches." Post-Theory: Reconstructing Film Studies. Ed. David Bordwell and Noel Carroll. Madison, WI: U of Wisconsin P, 1996. 307-24. Print.

Plato. The Republic. Trans. H. D. P. Lee. Harmondsworth: Penguin, 1953. Print.

Plotinus. Enneads. Vol. 5. Trans. A. H. Armstrong. Cambridge, MA: Harvard UP, 1984. Print. 
Porter, James L. The Sublime in Antiquity. Cambridge: Cambridge UP, 2016. Print.

Rubinstein, Paul, Lee H. Whittlesey, and Mike Stevens. The Guide to Yellowstone Waterfalls and Their Discovery. Englewood, CO: Westcliffe, 2000. Print.

Schuster, Mark. Don DeLillo, Jean Baudrillard, and the Consumer Conundrum. Youngstown, NY: Cambria, 2008. Print.

Sheff, David, and Victoria Sheff. "Ansel Adams: The Playboy Interview." Playboy 30.5 (May 1983). Davidsheff.com. Web. 8 Apr. 2018.

Silber, Marc. "Learn Ansel Adams' Biggest Secret for Stunning Photography_Visualization.” Digital-photography-school.com. Web. 8 Apr. 2018.

Stanley, Edwin James. Rambles in Wonderland: Or, Up the Yellowstone, and Among the Geysers and Other Curiosities of the National Park. New York: Appleton, 1878. Print.

Stewart, J. Riley. "A Study in Luminosity: What Photographers Can Learn from Other Artists." Jrileystewart.com. 3 Jan. 2015. Web. 8 Apr. 2018.

---. "Revelations About Art and Artists: Behind the 'Photographer's Eye."' Jrileystewart.com. 27 Feb. 2015. Web. 8 Apr. 2018.

Storrow, Benjamin. "Legacy of the Tetons: T. A. Moulton Barn Turns 100.” Billingsgazette.com. The Billings Gazette 4 July 2013. Web. 8 Apr. 2018.

Tabbi, Joseph, and Michael Wutz. Introduction. Reading Matters: Narrative in the Nerw Media Ecology. Ed. Joseph Tabbi and Michael Wutz. Ithaca, NY: Cornell UP, 1997. 1-25. Print.

Turnage, Robert. "Ansel Adams: The Role of the Artist in the Environmental Movement." The Living Wilderness 43.148 (1980). Anseladams.com. Web. 2 Apr. 2018.

Waypoint Tours. Yellowstone National Park Tour Guide Book. Scottsdale, AZ: Waypoint Tours, 2009. Print.

Weiskel, Thomas. The Romantic Sublime: Studies in the Structure and Psychology of Transcendence. Baltimore: John Hopkins UP, 1976. Print. Wilson, Keith. Viewefinder: 100 Top Locations for Great Travel Photography. Hove: RotoVision, 2004. Print.

David Allen is currently Artistic Director of the Midland Actors Theatre (MAT). He is the author of Performing Chekbov (Routledge, 2000) and Stanislavski for Beginners (1999). He has written several articles recently on Disney simulacra for the European Journal of American Culture, including "Seeing Double: Disney's Wilderness Lodge" (EJAC 31.2, 2012). He has also written a number of articles on Edward 
Bond, including "The Children" in Edward Bond and the Dramatic Child (Trentham, 2005) and "Between Brecht and Bond" in The Brecht Yearbook (2005).

news@midlandactorstheatre.co.uk

Agata Handley is Assistant Professor in the Faculty of Philology at the University of Łódź. She is the author of Constructing Identity: Continuity, Otherness and Revolt in the Poetry of Tony Harrison (Peter Lang, 2016) and is currently continuing her research on contemporary British literature. The main areas of her academic interest are contemporary British and Canadian poetry with particular focus on the culture of the English North.

agatagrazyna@gmail.com 